\title{
Pre and Post-monsoon Physico-chemical Assessment of Drinking Water Quality of Gandhinagar Area of Bhopal
}

\author{
H.C. KATARIA ${ }^{1}$ and SANTOSH AMBHORE ${ }^{2}$ \\ 1Department of Chemistry, Government Geetanjali Girls College, Bhopal - 462 038, India. \\ ${ }^{2}$ Department of Chemistry, Government Motilal Vigyan Mahavidalaya, Bhopal - 462 003, India.
}

(Received: July 12, 2012; Accepted: September 17, 2012)

\begin{abstract}
Physico-chemical assessment of drinking water quality of Gandhi Nagar area of Bhopal has evaluated in various stations for one year 2011-2012 in pre and post monsoon season. In this present study temperature, $\mathrm{pH}, \mathrm{BOD}, \mathrm{COD}, \mathrm{EC}$, free $\mathrm{CO}_{2}, \mathrm{~T}-\mathrm{H}, \mathrm{Ca}-\mathrm{H}, \mathrm{Mg}-\mathrm{H}$, total alkalinity has analyzed. The present study has its significance for public hygiene in public interest.
\end{abstract}

Key words: Parameters, physico-chemical assessment, pre and post monsoon, Hygiene, treatment, drinking water.

\section{INTRODUCTION}

The history of human civilization reveals that water supply and civilization are almost synonymous. several cities and civilizations have disappeared due to water shortage originating from climatic and other changes. The absence of water has resulted in the absence of life on the moon. Water, The nectar of life is one of the most important natural resource for all living organisms, whether unicellular or multicellular, since it is required for their various metabolic activities. In fact life on the earth is possible only because of the presence of abundant water. An understanding of water chemistry is the basis of knowledge of the multi dimensional aspects of aquatic environmental chemistry, which involve the source composition, reaction and transport of water. More than $71 \%$ of the earth's surface is covered by water, $97 \%$ of water is in oceans and not generally useful without treatment. The remaining $3 \%$ is fresh water and is found in rivers, lakes, and underground aquifers and locked up as ice. In fact, $79 \%$ of fresh water is in the form of ice mainly in two polar ice sheets and in the high mountain glaciers.
Rivers, lakes, man made reservoirs and underground water are our water wealth. Some centuries ago, water from these sources was clean and potable, but due to heavy industrialization, excessive use of fertilizers and pesticides, unscientifically disposal of sewage now a day's water pollution is the main problem for all living organisms.

Water quality is commonly defined by its physical, chemical, biological and aesthetic (appearance and smell) characteristics. A healthy environment is one in which the water quality supports a rich and varied community of organisms and protects public health."

The quality of drinking water is maintained by individual water bodies of all the metropolitan cities. Sydney Water and Hunter Water are the two large organisations that aim to provide high quality drinking water for all in these regions. Drinking water is treated to meet the Australian Drinking Water Guidelines(ADWG). ADWG is concerned with the safety and aesthetic quality of drinking water for human consumption. Drinking water does 
not need to be absolutely pure to be safe, as water is such a good solvent, pure water containing nothing else is almost impossible to attain. What is required is that drinking water should be safe to drink for people in most stages of normal life, including children over six months of age and the very old. It should contain no harmful concentrations of chemicals or pathogenic microorganisms, and ideally it should be aesthetically pleasing in regard to appearance, taste and odour.

Water quality has also become a big issue. The amount of clean water that is available has decreased within the past decade. Although some types of water pollution occur through natural processes, most of the pollution is caused by human activities. The water we use is taken from rivers, lakes and underground, and these are the same places the water returns to after we have finished using it - or actually, not finished using it but finished contaminating it. Water pollutants categorizes into four basic categories: pathogens and other organic materials, chemicals including organic and inorganic toxic substances, thermal heat, and suspended materials. Organic materials such as pesticides, fertilizers, plastics, detergents, gasoline, oil, factory waste water, and fossil fuels are among the most severe pollutants.

Many researchers have studied in detail the physic-chemical characteristics of groundwater ,rivers, lakes, water reservoirs and other water resources. The findings of some such work are relevant to the present study.

Present district of Bhopal was carved out of Sehore district in 1972. Bhopal is the picturesque capital of Madhya Pradesh and known as "city of lakes". Water is one of the very precious substances on the earth. it is very essential for the existence and survival of life. As population grows and their need for water increases, the pressure on our ground resources also increases . in many areas of the world ground water is now being over extracted, in some places massively so, the results is falling water levels and declining well yield ,land subsidence and ecological damage such as the drying out of wetlands.

Table 1: Physico-chemical assessment of drinking water of Gandhi Nagar Area of Bhopal City 2010-11

\begin{tabular}{|c|c|c|c|c|c|c|c|c|c|}
\hline \multirow[t]{2}{*}{ Parameters } & \multicolumn{8}{|c|}{ Mean Seasonal Value (Pre and Post monsoon ) } & \multirow[b]{2}{*}{$\mathrm{SS}_{8}$} \\
\hline & Unit & $\mathrm{SS}_{1}$ & $\mathrm{SS}_{2}$ & $\mathrm{SS}_{3}$ & $\mathrm{SS}_{4}$ & $\mathrm{SS}_{5}$ & $\mathrm{SS}_{6}$ & $\mathrm{SS}_{7}$ & \\
\hline Temperature & ${ }^{\circ} \mathrm{C}$ & 19 & $18^{*}$ & 21 & 20 & 19 & $24^{\star \star}$ & 22 & 23 \\
\hline $\mathrm{pH}$ & - & 5.00 & $4.5^{*}$ & 6.24 & 6.50 & 5.80 & 6.40 & $7.4^{\star \star}$ & 7.20 \\
\hline Electrical conductivity & $\begin{array}{l}\mu \text { mhos } \\
/ \mathrm{cm}\end{array}$ & 220 & $212^{*}$ & 310 & $418^{\star \star}$ & 232 & 278 & 232 & 384 \\
\hline Free $\mathrm{CO}_{2}$ & ppm & 6.42 & $6.20^{*}$ & 8.42 & 9.12 & 7.42 & $11.80^{\star *}$ & 10.94 & 11.20 \\
\hline Total Alkalinity & ppm & 216 & $240^{\star *}$ & 232 & 182 & 152 & 220 & 142 & $110^{*}$ \\
\hline Total Hardness & ppm & 212 & 224 & $420^{* *}$ & 312 & 216 & 284 & $210^{*}$ & 238 \\
\hline Calcium Hardness & ppm & 117 & 130 & $290^{* *}$ & 208 & $110^{*}$ & 190 & 114 & 178 \\
\hline Magnesium Hardness & ppm & 95 & 94 & $130^{* *}$ & 104 & 106 & 94 & 96 & $60^{*}$ \\
\hline Dissolved Oxygen & ppm & 2.12 & $2.40^{\star \star}$ & 1.82 & 2.10 & $1.10^{\star}$ & 2.32 & 1.72 & 2.26 \\
\hline B.O.D. & ppm & $4.92^{* *}$ & 1.52 & 2.18 & 1.60 & 3.28 & 2.16 & $1.42^{*}$ & 4.60 \\
\hline C.O.D. & ppm & 13.20 & $12.12^{\star}$ & 17.20 & $52.2^{\star \star}$ & 16.80 & 14.10 & 17.40 & 12.80 \\
\hline
\end{tabular}

$\begin{array}{ll}\mathrm{SS}_{1}=\text { Sant Aasharam Bapu Asharam } & \mathrm{SS}_{5}=\text { Sector no. } 11 \\ \mathrm{SS}_{2}=\text { Tagore ward } & \mathrm{SS}_{6}=\text { Parewakhedi } \\ \mathrm{SS}_{3}=\text { Gondipura } & \mathrm{SS}_{7}=\text { Dobra } \\ \mathrm{SS}_{4}=\text { Rajiv Gandhi technology university } & \mathrm{SS}_{8}=\text { Chandpur } \\ * *=\text { maximum value } & *=\text { minimum value }\end{array}$




\begin{abstract}
Water samples of bore-wells are collected in 2 litre clean polythene jerry-cane after flushing the bore wells to analysis. The procedure has adopted as prescribed by APHA (1985), NEERI(1986), presterilized bottles are used to collect DO and BOD samples. In present study temperature varied from $18-24{ }^{\circ} \mathrm{C}$. $\mathrm{pH}$ ranges as 4.50-7.40 indicates the intensity of acidity. Free $\mathrm{CO}_{2}$ ranges from 6.20-11.80 ppm, Electrical conductivity 212-418, total alkalinity $110-240 \mathrm{ppm}, \mathrm{DO}, \mathrm{BOD}$ and COD ranges as $1.10-2.40,1.42-4.92$, and 12.12-52.20 .Total Hardness, $\mathrm{Ca}-\mathrm{H}, \mathrm{Mg}-\mathrm{H}$ ranges as $210-420,110-290$, and $60-130$ ppm respectively as summarized in table-1. eight sampling stations are as follows:
\end{abstract}

1. Sant Aasharam Bapu aashram

2. Tagore ward

3. Gondipura

4. Rajiv Gandhi Technology University

5. Sector No-11

6. Parewakhedi

$7 . \quad$ Dobra

8. Chandpur

The above findings are similar with those of Handa (1994), Kataria (1995); 2000, 2004. Most of the parameters are found well with in the recommended limits of BIS and some parameters are found beyond the limits. Hence water samples analyzed in present study has found suitable for drinking purpose after proper required treatment.

\section{REFERENCES}

1. Standard method for the examination of water and waste water APHA, $13^{\text {th }}$ Ed. New York (1985).

2. NEERI: manual on water and waste water analysis, national environmental engineering research institute Nagpur 340 (1986).

3. BIS: specification for drinking water IS: 10500: Bureau of Indian standards, New Delhi (1991).

4. WHO: guideline for drinking water quality volume 1 (1984).

5. B.M. Bheshdadia, D.S. Kundariya and P.K. Patel, Orient J. Chem., 27(2): 685-689 (2011).

6 Kataria, H. C., Analytical study of trace elements in ground water of Bhopal City Ind. J. Environment Prot. IJEP, 24(12): 894-896 (2004).
7. Kataria, H.C. Preliminary study of drinking water of Pipariya township, Poll, Res, 19(4): 645-649 (2000).

8. WHO, Environmental health criteria, 5, Genewa (1978).

9. APHA : Standards methods for the examination of water and waste water, American Public Health Association (Greenberg, AE, Clexri, L.S. and Eaton A.D., $18^{\text {th }}$ ed. Washington DC. ) (1992)

10. Iqbal S.A.,Khan S.S.,Chaghtai S.A. and Irfan Husain; Assesment of pollution levels of river Betwa, J.Sci.Res., 6(3): 165-170 (1984).

11. C.N. Sawyer, et.al, chemistry for Environmental Engineering and Science, Fifth edition by Tata McGraw-Hill 659-665 (2003).

12. B.D. Gharde, Orient. J. Chem., 26(1): 175180 (2010). 